\title{
Korelasi antara kompetensi digital dan keterampilan berpikir kreatif mahasiswa pendidikan fisika
}

\author{
Yanti Sofi Makiyah \\ Pendidikan Fisika, Universitas Siliwangi, Indonesia \\ Surat-e: yanti.sofi@unsil.ac.id

\section{Nana} \\ Pendidikan Fisika, Universitas Siliwangi, Indonesia \\ Surat-e: nana@unsil.ac.id
}

\section{Ifa Rifatul Mahmudah}

Pendidikan Fisika, Universitas Siliwangi, Indonesia

Surat-e: ifa.rifatul@unsil.ac.id

\begin{abstract}
Abstrak. Mahasiswa Pendidikan Fisika harus memiliki kompetensi digital dan kemampuan berpikir kreatif abad 21, sehingga kompetensi tersebut harus dilatihkan bagi Mahasiswa Pendidikan Fisika. Salah satu cara untuk melatih kompetensi dan keterampilan tersebut dengan menerapkan model pembelajaran berbasis proyek dalam pembelajaran fisika. Penelitian ini merupakan penelitian kuantitatif non eksperimental dalam penelitian korelasional, bertujuan untuk mengetahui hubungan antara kompetensi digital dan keterampilan berpikir kreatif. Subjek penelitian terdiri dari 65 Mahasiswa Pendidikan Fisika yang mengambil mata kuliah Mekanika tahun ajaran 2019/2020 dengan menggunakan instrumen penelitian yaitu lembar observasi kompetensi digital, lembar observasi keterampilan berpikir kreatif, dan wawancara yang dilakukan oleh tiga orang observer. Berdasarkan hasil analisis data dapat disimpulkan bahwa terdapat korelasi positif yang sangat tinggi antara kompetensi digital dan keterampilan berpikir kreatif dengan nilai koefisien korelasi 0,84 dan kontribusi kompetensi digital terhadap keterampilan berpikir kreatif sebesar $71 \%$.
\end{abstract}

Kata kunci: kompetenci digital, keterampilan berpikir kreatif, project based learning

\begin{abstract}
Physics education students must possess digital competence and creative thinking skills in the 21st century, so these competencies must be trained for Physics Education Students. One way to train these competencies and skills to apply a project-based learning model in physics learning. This research is non-experimental quantitative research in correlational research, aiming to determine the relationship between digital competence and creative thinking skills. The research subjects consisted of 65 Physics Education Students taking Mechanics courses for the 2019/2020 academic year using research instruments, namely digital competency observation sheets, creative thinking skills observation sheets, and interviews conducted by three observers. Based on the data analysis results, it is concluded that there is a very high positive correlation between digital competence and creative thinking skills with a correlation coefficient value of 0.84 and the contribution of digital competence to creative thinking skills by $71 \%$.
\end{abstract}

Keywords: digital comptence, creative thinking skills, project based learning 


\section{Pendahuluan}

Mahasiswa Pendidikan Fisika sebagai calon guru fisika harus memiliki kompetensi dan keterampilan yang dibutuhkan pada abad 21 karena mahasiswa dituntut untuk memiliki kreativitas, memberikan inovasi, berpikir kritis, memecahkan masalah dan terampil berkomunikasi [1]. Oleh karena itu, keterampilan berpikir kreatif (creative thinking skills) dan kompetensi digital (digital competence) harus dilatihkan dalam pembelajaran di universitas karena menjadi kualifikasi baru seorang guru profesional di abad 21 dalam mengembangkan pembelajaran di kelas menggunakan sumber dan media digital yang menjadi bagian dari kehidupan sehari-hari seorang guru [2]. Selain itu, kompetensi digital dan keterampilan berpikir kreatif juga menjadi dasar yang penting dalam merancang dan melaksanakan pembelajaran di abad 21 [3].

Kompetensi digital (digital competence) merupakan salah satu kompetensi dari 8 kompetensi yang direkomendasikan di Eropa tahun 2016 untuk pembelajaran seumur hidup (lifelong learning). Kompetensi digital dapat didefinisikan secara luas sebagai penggunaan Teknologi Informasi dan Komunikasi (TIK) secara percaya diri, kritis dan kreatif untuk mencapai tujuan yang terkait dengan pekerjaan, kelayakan kerja, pembelajaran atau partisipasi dalam masyarakat [4]. Kompetensi digital pendidik sangat erat kaitannya dengan kecakapan pendidik dalam menggunakan TIK berdasarkan kaidah pedagogis dengan menyadari implikasinya terhadap metodologi pendidikan. Kompetensi digital pendidik dibagi ke dalam beberapa bentuk, yaitu: information, communication, educational content creation, security dan educational problem solving [5]. Kompetensi digital juga sebagai kualifikasi untuk guru profesional dalam kelas digital dengan aspek penilaian meliputi penggunaan alat digital (aplikasi digital) untuk melaksanakan pembelajaran siswa, untuk membuat media dan evaluasi pembelajaran fisika, untuk pekerjaan administrasi sekolah dan pemahaman etika tentang penggunaan media sosial [6]. Oleh karena itu, mahasiswa pendidikan fisika sebagai calon guru fisika yang akan memiliki peranan penting di dunia pendidikan harus dibekali kompetensi digital.

Keterampilan berpikir kreatif (creative thinking skills) merupakan salah satu keterampilan abad 21 yang harus dimiliki oleh Mahasiswa Pendidikan Fisika sebagai calon guru profesional di abad 21 yang dituntut dapat merancang dan melaksanakan pembelajaran dengan memaksimalkan TIK sehingga keterampilan ini perlu dilatihkan dalam pembelajaran di Universitas. Keterampilan ini diperlukan agar dapat mengatasi keterbatasan dan memudahkan pembelajaran dengan menggunakan aplikasi digital. Ada beberapa indikator keterampilan berpikir kreatif yaitu berpikir lancar, luwes, orisinal, elaboratif dan evaluatif [7].

Berdasarkan hasil studi pustaka dari penelitian yang telah dilakukan kepada Mahasiswa Pendidikan Fisika di Universitas Siliwangi menunjukkan bahwa rata-rata kompetensi literasi informasi dan data digital masih dalam kategori rendah dengan nilai 36, rata-rata skor kompetensi komunikasi dan kolaborasi dalam kategori sedang dengan nilai 68, dan rata-rata skor kompetensi kreasi konten digital masih rendah dengan nilai 47 [8]. Hasil studi pendahuluan yang dilakukan juga menyatakan bahwa mahasiswa belum mendapatkan pelatihan peningkatan kompetensi digital dan keterampilan berpikir kreatif dalam perkuliahan. Oleh sebab itu, maka diperlukan pembelajaran yang dapat melatihkan dan mengembangkan kompetensi digital mahasiswa sekaligus melatihkan salah satu keterampilan abad 21 yaitu keterampilan berpikir kreatif. Penelitian sebelumnya menyatakan bahwa penerapan Project-Based Learning dapat meningkatkan keterampilan berpikir kreatif dalam kategori baik pada materi asam basa [9]. Penelitian lain menyatakan hasil yang sesuai bahwa ProjectBased Learning dapat meningkatkan keterampilan berpikir kreatif mahasiswa pada materi usaha dan energi karena kegiatan perkuliahan lebih menarik, bermakna dan membantu mahasiswa mengkonstruk pengetahuan secara mandiri melalui proyek yang dikerjakan [10]. Hasil penelitian selanjutnya juga menyatakan bahwa pembelajaran berbasis Project-Based Learning dapat meningkatkan keterampilan berpikir kreatif dalam kategori sedang pada materi fluida statis [11]. Selain itu, penelitian terbaru menyatakan bahwa perkuliahan berbasis Project-Based Learning dapat digunakan dalam proses pembelajaran bagi mahasiswa Program Studi Pendidikan Fisika karena efektif meningkatkan pengetahuan, sikap dan keterampilan mahasiswa [12]. Adapun penelitian sebelumnya tentang hubungan kreativitas dan berpikir kritis melalui Problem-Based Learning (PjBL) dengan kompetensi digital dalam membuat mind maps di kelas anatomi dan fisiologi manusia menunjukkan hubungan yang signifikan dengan kategori sedang [13]. Penelitian lain juga menunjukkan hasil yang sama bahwa antara keterampilan abad 21 dan kompetensi digital mahasiswa di Cina dalam digital citizenship memiliki hubungan yang positif dengan kategori sedang [14].

Peneliti berdasarkan latar belakang tersebut tertarik untuk melakukan penelitian tentang korelasi antara komptensi digital dengan keterampilan berpikir kreatif Mahasiswa Pendidikan Fisika melalui penerapan model yang berbeda dengan penelitian sebelumnya yaitu memilih Project-Based Learning (PjBL) yang dinilai dapat 
mengembangkan keterampilan berpikir kreatif sehingga ini menjadi kebaharuan untuk mengetahui hubungan kedua variabel dan kontribusinya dalam melatihkan kompetensi dan keterampilan yang dibutuhkan di abad 21 . Selain itu, proyek-proyek yang dihasilkan mahasiswa dapat digunakan dan dimanfaatkan bukan hanya oleh mahasiswa saja tetapi guru fisika juga dalam pembelajaran fisika di sekolah.

\section{Metode Penelitian}

Penelitian yang dilakukan yaitu penelitian kuantitatif non eksperimental berupa penelitian korelasional untuk mengetahui hubungan antara kompetensi digital dan keterampilan berpikir kreatif serta untuk mengetahui kontribusi dari kompetensi digital terhadap keterampilan berpikir kreatif mahasiswa pendidikan fisika di Universitas Siliwangi [15]. Penelitian dilakukan dalam perkuliahan mekanika tahun akademik 2019/2020 terdiri dari 2 kelas dengan jumlah 65 mahasiswa dengan menerapkan model project-based learning ( $\mathrm{PjBL}$ ) hasil adaptasi model 4-D meliputi proses define, design, develop, dan disseminate [16]. Perkuliahan menerapkan model Project-Based Learning dimulai dengan dosen mengajukan beberapa pertanyaan sebagai dasar penugasan suatu proyek (start with the essential question) kemudian mahasiswa membuat rencana desain proyek (design a plan for the project) secara kolaboratif dan menyusun jadwal aktivitas (create a schedule) dalam menyelesaikan proyek selanjutnya dosen melakuan monitor terhadap aktivitas mahasiswa (monitor the progress of the project) selama menyelesaikan proyek dan mengevaluasi kemajuan dari proyek (assess the outcome) yang sedang dikerjakan mahasiswa serta memberikan umpan balik kemudian dosen dan mahasiswa melakukan evaluasi (evaluate the experience) terkait aktivitas dan hasil proyek yang dihasilkan. Tahapan 4-D digunakan dalam mengembangkan proyek yang sedang dikerjakan oleh mahasiswa selama perkuliahan ketika menerapkan model Project-Based Learning. Pada tahap define, mahasiswa mengidentifikasi masalah dalam proses pembelajaran sebagai dasar perancangan proyek kemudian menganalisis kebutuhan dan materi pembelajaran. Selanjutnya pada tahap design, mahasiswa membuat proyek dengan menggunakan aplikasi digital terkait media dan evaluasi pembelajaran serta pekerjaan administrasi sekolah. Tahap berikutnya yaitu tahap develop, mahasiswa melakukan pengembangan proyek yang dibuat setelah merevisi kekurangan berdasarkan penilaian observer dan teman sejawat. Pada tahap disseminate, mahasiswa menyebarluaskan hasil proyek yang telah dibuat di media sosial seperti Youtube, Instagram dan Twitter. Untuk lebih jelasnya dapat dilihat alur proses pembelajaran sebagai berikut.

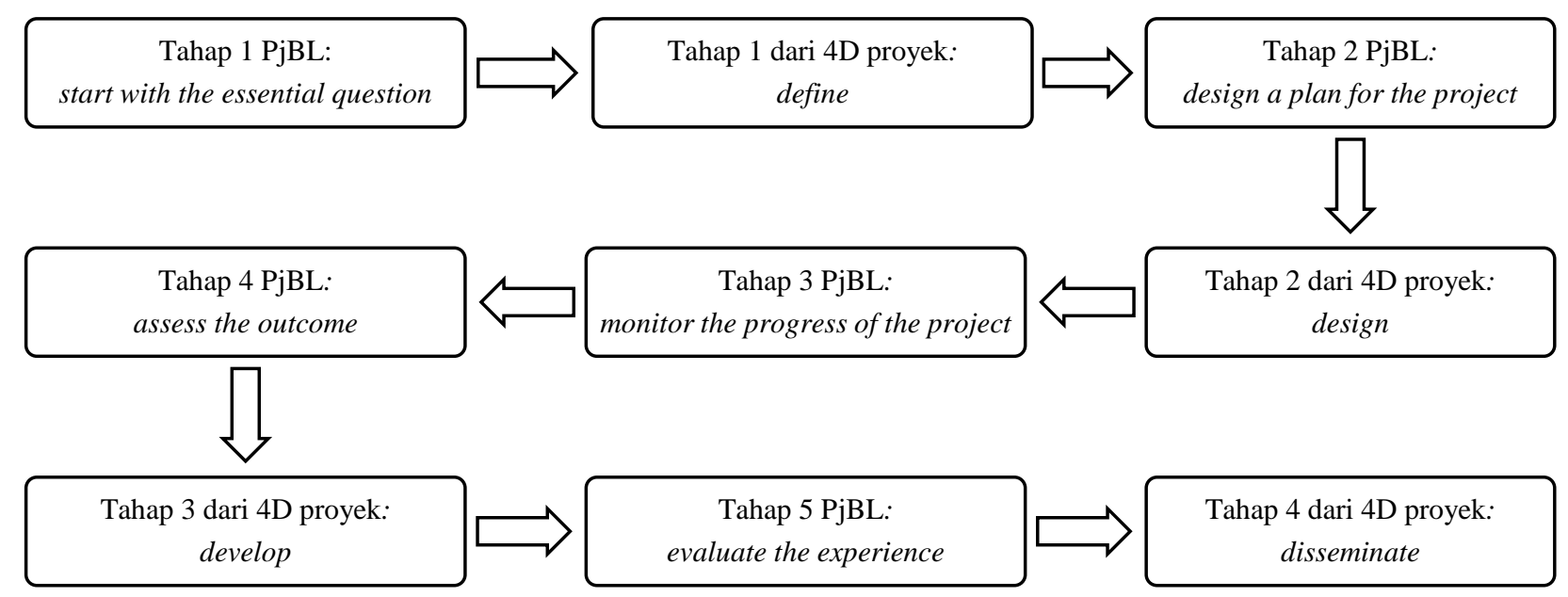

Gambar 1. Alur proses pembelajaran menerapkan PjBL dan 4-D dalam mengembangkan proyek

Data diperoleh melalui lembar observasi kompetensi digital, lembar observasi keterampilan berpikir kreatif dan wawancara. Lembar observasi kompetensi digital meliputi 4 aspek penilaian yaitu (1) penggunaan alat digital (aplikasi digital) untuk melaksanakan pembelajaran siswa, (2) penggunaan alat digital (aplikasi digital) untuk media dan evaluasi pembelajaran fisika, (3) pengembangan pemahaman tentang penggunaan alat digital (aplikasi digital) untuk pekerjaan administrasi sekolah dan (4) pemahaman tentang etika yang 
terkait dengan penggunaan media sosial. Untuk lebih jelasnya skor penilaian kompetensi digital dapat dilihat pada Tabel 1.

Tabel 1. Aspek penilaian kompetensi digital

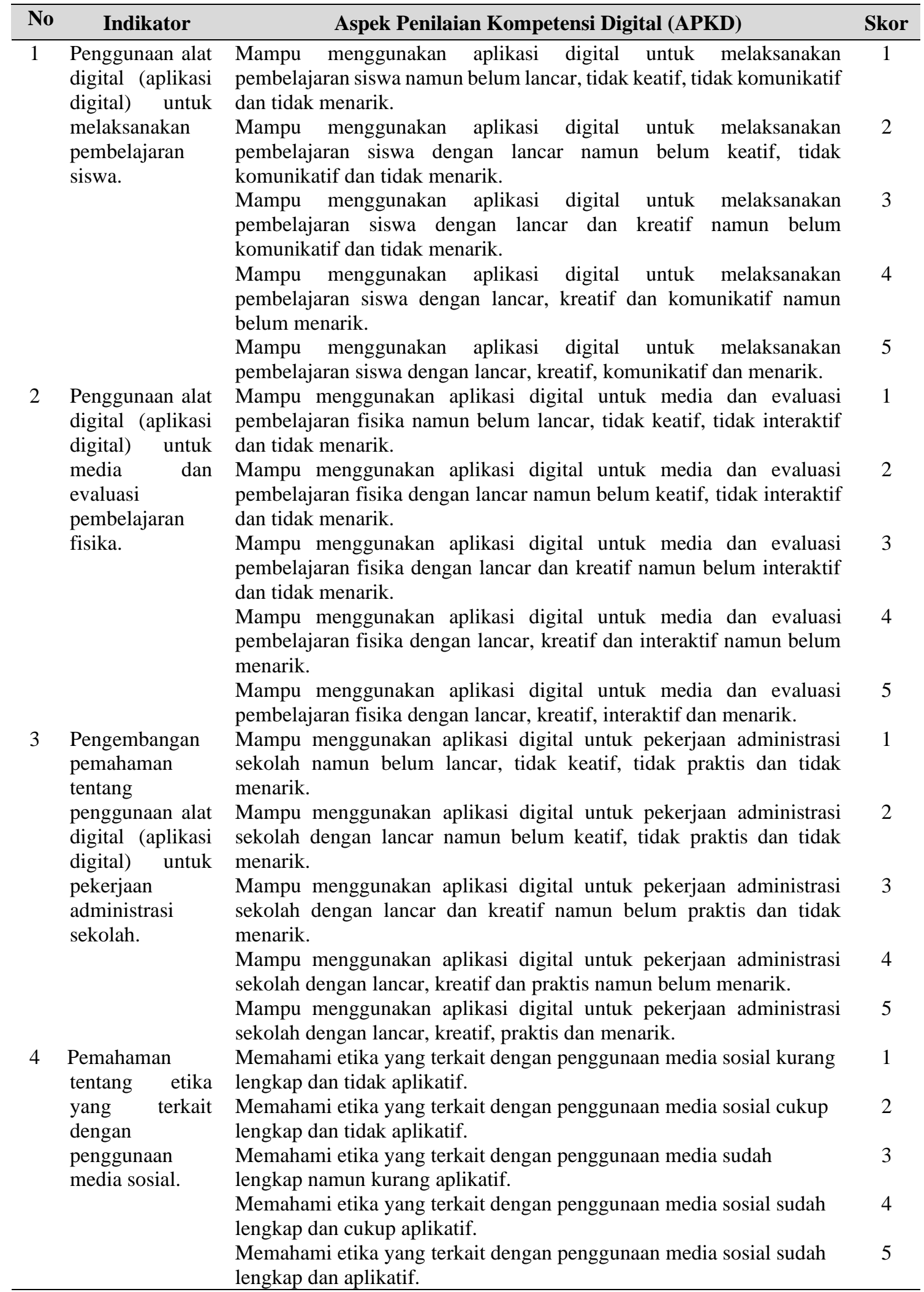


Adapun lembar observasi keterampilan berpikir kreatif yang dinilai terdiri dari 5 indikator yaitu (1) berpikir lancar, (2) berpikir luwes, (3) berpikir orisinal, (4) berpikir elaboratif dan (5) berpikir evaluatif dengan aspek penilaian seperti pada Tabel 2 .

Tabel 2. Penilaian keterampilan berpikir kreatif

\begin{tabular}{|c|c|c|}
\hline No & Indikator & Aspek Penilaian \\
\hline 1 & Berpikir lancar & $\begin{array}{l}\text { 1. Mengajukan berbagai pertanyaan. } \\
\text { 2. Menjawab pertanyaan dengan berbagai jawaban. } \\
\text { 3. Bekerja lebih cepat daripada teman yang lain. } \\
\text { 4. Lebih berkontribusi daripada teman yang lain. }\end{array}$ \\
\hline 2 & Berpikir luwes & $\begin{array}{l}\text { 1. Mempunyai berbagai penafsiran terhadap suatu sesuatu yang } \\
\text { diberikan atau disajikan dapat berupa gambar, cerita atau } \\
\text { permasalahan. } \\
\text { 2. Menerapkan konsep tertentu dengan cara yang berbeda. } \\
\text { 3. Menyampaikan pertimbangan atau pendapat yang berbeda, unik dan } \\
\text { out of the box dari mayoritas kelompok. } \\
\text { 4. Mampu membangun keterkaitan antar konsep. }\end{array}$ \\
\hline 3 & Berpikir orisinal & $\begin{array}{l}\text { 1. Memikirkan sesuatu hal yang tidak terpikirkan oleh orang lain. } \\
\text { 2. Kritis terhadap cara yang lama dan berusaha melakukan inovasi baru. } \\
\text { 3. Menyampaikan inovasi baru dalam menyelesaikan permasalahan. } \\
\text { 4. Melakukan inovasi baru setelah mendapatkan ide atau gagasan yang } \\
\text { baru. }\end{array}$ \\
\hline 4 & Berpikir elaboratif & $\begin{array}{l}\text { 1. Mencari jawaban atau solusi dengan langkah yang sistematis. } \\
\text { 2. Mengembangkan ide atau gagasan orang lain. } \\
\text { 3. Menjawab dan memberikan solusi yang komprehensif dan } \\
\text { memuaskan. } \\
\text { 4. Menghubungkan berbagai konsep untuk ide atau gagasan baru. }\end{array}$ \\
\hline 5 & Berpikir evaluatif & $\begin{array}{l}\text { 1. Menyampaikan pendapat atau pertimbangan dengan sudut pandang } \\
\text { sendiri yang unik, menarik dan inovatif. } \\
\text { 2. Menganalisis solusi secara kritis dengan mempertanyakan alasan } \\
\text { logisnya. } \\
\text { 3. Menyampaikan alasan yang dapat dipertanggungjawabkan dalam } \\
\text { memberikan keputusan permasalahan. } \\
\text { 4. Menyampaikan pendapat dan mempertahankannya dengan alasan } \\
\text { yang kuat. }\end{array}$ \\
\hline
\end{tabular}

Hasil penilaian lembar observasi kompetensi digital dan lembar observasi keterampilan berpikir kreatif dari ketiga observer selanjutnya dikategorikan berdasarkan kriteria sesuai pada Tabel 3.

Tabel 3. Kriteria penilaian kompetensi digital dan keterampilan berpikir kreatif

\begin{tabular}{ccc}
\hline No & Kategori & Skor \\
\hline 1 & Baik & $14-20$ \\
2 & Cukup & $8-13$ \\
3 & Kurang & $1-7$ \\
\hline
\end{tabular}

Wawancara dilakukan pada setiap kelompok dengan memberikan 10 pertanyaan yang sudah disiapkan sebelumnya untuk menggali dan melengkapi data secara mendalam.

\section{Hasil Penelitian dan Pembahasan}

Berdasarkan hasil analisis data diketahui bahwa kompetensi digital dan keterampilan berpikir kreatif mahasiswa pendidikan fisika berada dalam ketegori baik seperti yang ditunjukkan pada Gambar 2 . 


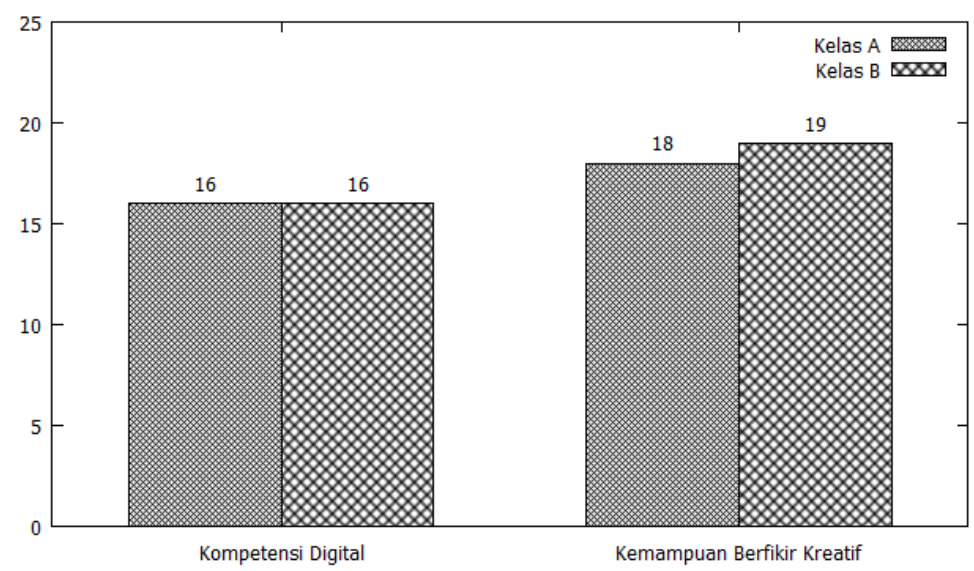

Gambar 2. Hasil observasi kompetensi digital dan keterampilan berpikir kreatif

Berdasarkan data tersebut dan hasil wawancara diketahui bahwa Mahasiswa Pendidikan Fisika memiliki kompetensi digital yang baik karena mahasiswa mampu membuat menggunakan berbagai aplikasi digital dalam membuat presentasi yang baik. Adapun aplikasi digital yang digunakan mahasiswa pendidikan fisika dalam membuat media pembelajaran yaitu Tondoon, Kahoot, Pixtoon, PhET simulation, Webtoon, Storyboardthat, Google Classroom, Circuit Wizard, Corel Video, Edmodo, Wizzard, Proteus, Picsart, Moodle, Electric sircuit video dan Logic gate simulation. Mahasiswa pendidikan fisika juga membuat evaluasi pembelajaran fisika menggunakan aplikasi yaitu Kahoot, Google Form, Kazon, Quiz, Ms. Excel dan Canva. Mahasiswa dapat menggunakan aplikasi digital dengan menarik dan komunikatif, praktis dan aplikatif. Beberapa mahasiswa pendidikan fisika memiliki kompetensi digital sangat baik karena ketertarikannya terhadap teknologi digital sangat tinggi.

Hasil pengamatan kompetensi digital pada setiap aspek dari kedua kelas memiliki rata-rata yang sama karena setelah diobservasi dari kedua kelas tersebut jumlah mahasiswa dalam kategori baik, cukup dan kurangnya juga hampir sama sehingga rata-rata setiap aspek penilaian kompetensi digital kedua kelas juga sama atau dengan kata lain kedua kelas tersebut homogen kompetensi digitalnya. Selain itu, Mahasiswa Pendidikan Fisika angkatan 2018 memiliki pengetahuan beberapa aplikasi dari mata kuliah lain seperti media pembelajaran sehingga pemahaman dan penggunaan aplikasi digital sudah baik. Ini sesuai dengan penelitian yang telah dilakukan oleh A. Çebi bahwa dosen harus fokus melakukan pelatihan atau memberikan aktivitas kepada mahasiswa supaya mengorganisir apa yang dibutuhkan oleh mahasiswa dalam meningkatkan komptensi digital [17].

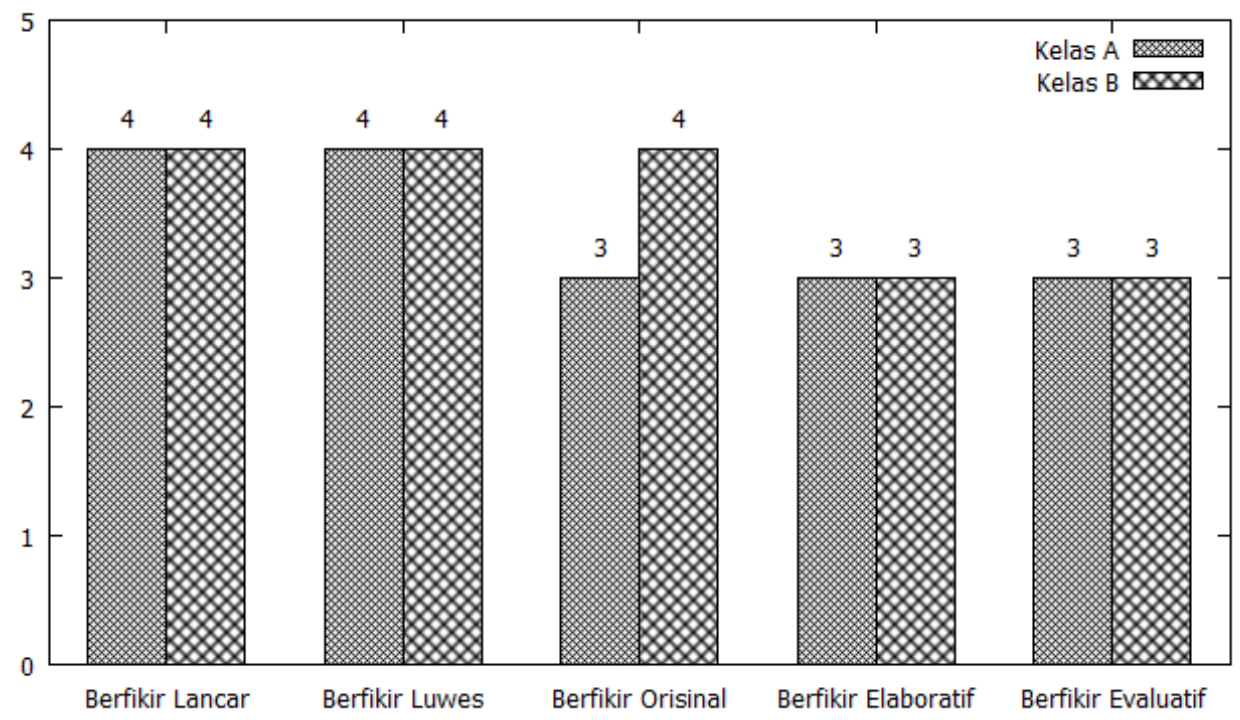

Gambar 4. Hasil observasi keterampilan berpikir kreatif pada setiap indikator 
Selanjutnya, hasil uji korelasional menunjukkan bahwa korelasi antara kompetensi digital dengan keterampilan berpikir kreatif merupakan korelasi yang positif dalam kategori tinggi sekali seperti ditunjukkan pada tabel berikut.

Tabel 4. Hasil uji korelasional

\begin{tabular}{ccc}
\hline Kelas & Koefisien korelasi $(\mathbf{r})$ & Kategori \\
\hline A & 0,86 & Tinggi sekali \\
B & 0,82 & Tinggi sekali \\
Rata-rata & 0,84 & Tinggi sekali \\
\hline
\end{tabular}

Berdasarkan hasil uji korelasional tersebut maka dapat dinyatakan bahwa semakin tinggi kompetensi digital mahasiswa maka semakin tinggi juga keterampilan berpikir kreatifnya. Kompetensi digital Mahasiswa Pendidikan Fisika menjadi faktor yang sangat mendukung sekali dalam pembuatan proyek yang diberikan oleh dosen. Kompetensi digital dan keterampilan berpikir kreatif saling berkontribusi satu sama lain dalam pembuatan proyek yang kreatif dengan kontribusi sebesar $71 \%$. Hasil tersebut sesuai dengan penelitian sebelumnya oleh N. Soroko yang menyatakan bahwa kompetensi digital mahasiswa merupakan faktor yang signifikan dalam membuat sesuatu yang kreatif dan mendukung pembelajaran mahasiswa [18]. Penelitian lain juga menyatakan hal yang sama bahwa kompetensi digital dan keterampilan berpikir kreatif dapat berkolaborasi dengan lebih baik dan saling mendukung satu sama lain dalam proses pengembangan mahasiswa [19]. Hasil penelitian yang diperoleh ini sejalan dengan penelitian yang dilakukan E. V. Laar bahwa korelasi antara KD dan KBK sangat relevan berdasarkan kajian literatur yang sistematik di abad 21 [20]. Hasil penelitian lain yang dilakukan oleh F. M. Esteve-Mon menyatakan terdapat korelasi yang positif antara KD dengan keterampilan berpikir mahasiswa terutama dalam aspek komunikasi dan teknologi. Informasi yang relevan akan membuka jalan dalam pengembangan dan pelatihan mahasiswa [21].

\section{Kesimpulan}

Berdasarkan hasil analisis data maka dapat disimpulkan bahwa terdapat korelasi positif dalam kategori sangat tinggi antara kompetensi digital dan keterampilan berpikir kreatif. Selain itu, kontribusi kompetensi digital besar terhadap keterampilan berpikir kreatif yaitu $71 \%$. Jadi, kompetensi digital dapat dilatihkan kepada Mahasiswa Pendidikan Fisika untuk menunjang keterampilan berpikir kreatif dalam merancang dan melaksanakan pembelajaran, membuat media dan evaluasi pembelajaran serta mempermudah pekerjaan administrasi sekolah melalui penerapan model Project-Based Learning. Penelitian selanjutnya dapat mengembangkan cara lain untuk melatihkan kompetensi digital dan keterampilan berpikir kreatif dengan menerapkan model pembelajaran atau strategi lain yang sesuai.

\section{Ucapan Terimakasih}

Ucapan terima kasih kepada semua pihak yang terlibat dalam peneletian ini terutama Kepada Mahasiswa Pendidikan Fisika angkatan 2018 atas kerja sama dan semangatnya selama proses penelitian sehingga kami beresonansi dan bersinergi dalam melaksanakan penelitian, para dosen dan ketua jurusan pendidikan fisika di Universitas Siliwangi yang saling membantu dan memotivasi dalam melaksanakan penelitian.

\section{Kepustakaan}

[1] Y. S. Makiyah, A. Malik, E. Susanti, and I. R. Mahmudah, "Higher Order Thinking Real and Virtual Laboratory (HOTRVL) untuk Meningkatkan Keterampilan Abad Ke-21 Mahasiswa Pendidikan Fisika," Diffraction, vol. 1, no. 1, pp. 34-38, 2019.

[2] Gudmundsdottir, "Newly Qualified Teachers' Professional Digital Competence: Implications for Teacher Education," Eur. J. Teach. Educ., vol. 41, no. 2, pp. 214-231, 2008.

[3] R. D. Prayogi and R. Estetika, "Kecakapan Abad 21 : Kompetensi Digital Pendidik Masa Depan," J. Manaj. Pendidik., vol. 14, no. 2, pp. 144-151, 2019, doi: 10.23917/mp.v14i2.9486.

[4] A. Ferrari, "Digital Competence in Practice: An Analysis of Frameworks," Jt. Res. Cent. Eur. Comm., p. 91, 2013, doi: 10.2791/82116.

[5] M. Spante, S. S. Hashemi, M. Lundin, and A. Algers, "Digital competence and digital literacy in higher 
education research: Systematic review of concept use," Cogent Educ., vol. 5, no. 1, pp. 1-21, 2018, doi: 10.1080/2331186X.2018.1519143.

[6] E. López-Meneses, F. M. Sirignano, E. Vázquez-Cano, and J. M. Ramírez-Hurtado, "University students' digital competence in three areas of the DigCom 2.1 model: A comparative study at three European universities," Australas. J. Educ. Technol., vol. 36, no. 3, pp. 69-88, 2020, doi: 10.14742/AJET.5583.

[7] R. Medriati and E. Risdianto, "Penerapan Pendekatan Student Centered Learning (SCL) Untuk Meningkatkan Keterampilan Berpikir Kreatif Dan Komunikatif Mahasiswa Pendidikan Fisika Semester Iii Universitas Bengkulu," J. Kumparan Fis., vol. 3, no. 1, pp. 67-74, 2020, doi: 10.33369/jkf.3.1.67-74.

[8] R. Rizal, D. Rusdiana, W. Setiawan, and P. Siahaan, "The Digital Literacy of The First Semester Students in Physics Education,” J. Pendidik. Fis., vol. 8, no. 2, pp. 101-110, 2020, doi: 10.26618/jpf.v8i2.3293.

[9] R. Ayu Candra, A. Tri Prasetyra, and R. Hartati, "Analisis Kemampuan Berpikir Kreatif Peserta Didik Melalui Penerapan Blended Project Based Learning,” J. Inov. Pendidik. Kim., vol. 13, no. 2, pp. 2437-2446, 2019.

[10] A. Asra, Ratnawulan, and Yulkifli, "Pengembangan perangkat pembelajaran fisika dasar i model pembelajaran project based learning di prodi pendidikan fisika universitas pasir pengaraian," J. Ilm. Edu Res., vol. 4, no. 2, pp. 71-80, 2015.

[11] N. K. Novianto, M. Masykuri, and S. Sukarmin, "Pengembangan Modul Pembelajaran Fisika Berbasis Proyek (Project Based Learning) Pada Materi Fluida Statis Untuk Meningkatkan Kreativitas Belajar Siswa Kelas X Sma/ Ma," INKUIRI J. Pendidik. IPA, vol. 7, no. 1, pp. 81-92, 2018, doi: 10.20961/inkuiri.v7i1.19792.

[12] L. P. Sari, I. Hatchi, and M. Kahanna, "Modul Ajar Fisika Dasar Berbasis Model Project Based Learning ( PjBL ) yang Efektif Bagi Mahasiswa," J. Educ. Dev., vol. 8, no. 1, pp. 272-275, 2020.

[13] N. H. S. Zubaidah, E. Suarsini, and H. Praherdhiono, "Examining the Relationship between Creativity and Critical Thinking through Integrated Problem-based Learning and Digital Mind Maps," Univers. J. Educ. Res., vol. 7, no. 9, pp. 171-179, 2019.

[14] S. Xu, H. Yang, and S. Zhu, "An investigation of 21st-century digital skills on digital citizenship among college students," Proc. - 2019 Int. Symp. Educ. Technol. ISET 2019, pp. 236-240, 2019, doi: 10.1109/ISET.2019.00056.

[15] J. R. Fraenkel, N. E. Wallen, and H. A. Hyun, How to Design and Evaluate Research in Education. US: McGraw-Hill Comp, 2008.

[16] F. Y. Al-Hassawi, I. A.-R. Al-Zaghul, and F. A. Al-Jassim, "the Effect of a Project- Based Program To Develop the of Critical and Creative Thinking Skills," PEOPLE Int. J. Soc. Sci., vol. 6, no. 1, pp. 306-323, 2020, doi: 10.20319/pijss.2020.61.306323.

[17] A. Çebi and I. Reisoglu, "Digital competence: A study from the perspective of pre-service teachers in Turkey," J. New Approaches Educ. Res., vol. 9, no. 2, pp. 294-308, 2020, doi: 10.7821/naer.2020.7.583.

[18] N. Soroko and L. Mykhailenko, "Teachers' Digital Competence Development As an Important Factor for the Creation and Support of the Steam-Based Educational Environment," Порівняльно-Педагогічні Студї̈, vol. 0, no. 2, pp. 47-58, 2019, doi: 10.31499/2306-5532.2.2019.186784.

[19] E. J. Instefjord and E. Munthe, "Educating digitally competent teachers: A study of integration of professional digital competence in teacher education," Teach. Teach. Educ., vol. 67, pp. 37-45, 2017, doi: 10.1016/j.tate.2017.05.016.

[20] E. van Laar, A. J. A. M. van Deursen, J. A. G. M. van Dijk, and J. de Haan, "The relation between 21st-century skills and digital skills: A systematic literature review," Comput. Human Behav., vol. 72, pp. 577-588, 2017, doi: 10.1016/j.chb.2017.03.010.

[21] F. M. Esteve-Mon, M. Á. Llopis, and J. Adell-Segura, "Digital Competence and Computational Thinking of Student Teachers," Int. J. Emerg. Technol. Learn., vol. 15, no. 02, p. 29, 2020, doi: 10.3991/ijet.v15i02.11588. 